How to cite: Albu, L.-M., Enea, A., Stoleriu, C.C., Niacșu, L. (2019) G.I.S. Implementation on Dam-Break Flood Vulnerability Analysis - A Case Study of Cătămărăști Dam, Botoșani, Romania. 2019 "Air and Water - Components of the Environment" Conference Proceedings, Cluj-Napoca, Romania, p. 65-76, DOI: 10.24193/AWC2019 07.

\title{
G.I.S. IMPLEMENTATION ON DAM-BREAK FLOOD VULNERABILITY ANALYSIS - A CASE STUDY OF CĂTĂMĂRĂȘTI DAM, BOTOȘANI, ROMANIA
}

\author{
Liviu-Marian ALBU ${ }^{I}$ 凹, Andrei ENEA ${ }^{1,2}$, Constantin Cristian STOLERIU ${ }^{1}$, \\ Lilian NIACS U ${ }^{I}$
}

DOI: 10.24193/AWC2019_07

\begin{abstract}
Flood analysis has become a very important research topic in the last decade, mainly due to the spatial and temporal rainfall variability and river discharge. The construction of dams on rivers has helped in keeping a certain amount of safety from such phenomena among other advantages. However, the consequences of failure of these structures could generate massive damages such as loss of human lives and property damage or destruction. In order to mitigate the eventual threat of a dam-break flood and come up with strategies concerning the eventuality of the event, it is highly important to estimate the characteristics of the potential dam-break generated flood. For this study, a HEC-RAS two-dimensional model was used based on a LiDAR digital elevation model, in order to assess the dam-break flood vulnerability of the inhabited areas downstream of Cătămărăști Dam, an earth dam with a clay sealing, located 3 kilometers upstream of the first locality and the periphery of Botoșani city. The simulation involves the breaking of the dam at full capacity, namely 12.4 million cubic meters and the modelling of its entire water volume downstream movement. The results show the flood extent and the water depth, the vulnerable inhabited areas and land cover areas, exposed to the potential threat of the simulated flood, on the inhabitants located near the riverbed, with a total of 780.92 ha, a number of 698 households, constructions, several roads and bridges, vulnerable to the floods. For mapping the results and other GIS related tasks, ArcGIS software was used. Due to the given proximity of the inhabited areas downstream and the volume of Cătămărăști reservoir, the modelled scenario can be a probable event.
\end{abstract}

Keywords: HEC-RAS, dam-break, simulation, vulnerability, management

\section{INTRODUCTION}

In the modern civilization, water resources are a crucial factor in our present way of life. In the past century, the human society has developed tremendously especially through urbanization, industrialization and agricultural development that led to a continuous rise in water and electrical power demand, especially in areas

1 Alexandru Ioan Cuza University of Iasi, Faculty of Geography and Geology, Department of Geography, Bd. Carol I 20A, 700505, Iasi, Romania albuliviumarian@gmail.com, andr.enea@yahoo.com,cristoan@yahoo.com, lilianniacsu@yahoo.com

${ }^{2}$ Integrated Center of Environmental Science Studies in the North-Eastern Region-CERNESIM, 11 Carol I, 700506, Alexandru Ioan Cuza University of Iasi, Romania 
with water shortages or areas with low precipitations. For this reason, cities have been developed commonly near water resources like rivers. All across the Globe, as well as in Romania, a lot of dams were built, either to ensure protection from floods or to supply water and to produce electricity to meet the rising demand.

Unfortunately, some of the dams that were constructed upstream of densely populated areas are located in areas susceptible or with seismic activity. This strategy automatically implies a risk for the developed and populated areas near dams, in case they could fail. Even if these structures can ensure safety at first glance, disasters involving dam breaches and floods were recorded in the world in the recent history (Xu et al., 2008; Alcrudo and Mulet, 2007; Altinakar et al., 2010; Fu et al., 2018). In Romania, only one high amplitude dam failure was registered, in July 1991, involving Belci dam, constructed on Tazlău River (Enea, 2017). Two similar and more recent events happened on upper Tisa Basin, when two mining tailing dams failed in January respectively March, 2000, discharging a volume of approximately $200,000 \mathrm{~m}^{3}$ of cyanide and contaminated water, and 40,000 tons of tailings in the tributaries of Tisa River (Macklin et al., 2003).

There are different reasons that can lead to a dam failure, but in the case of earth dams, which are the most frequent type of dams, the main cause is represented by overtopping and piping (Singh, 1996; Zhang et al., 2016). In Romania, the lakes and ponds that are held by an earth dam count a few thousands and the highest dam failure risk comes from the lakes with high water volume (Romanescu et al., 2014).

Several studies concerning dam breaching simulations were conducted across the Globe. They address issues like peak flow estimation, flood analysis and mitigation methods, scenarios of dam breaching, model comparison etc., which are mentioned in the international literature. Among the most recent ones are: Hu H. et al., (2018); Zhong et al., (2017); Álvarez et al., (2017); Amini et al., (2017); Xu F. et al., (2016).

For Romania, there are fewer studies addressing this subject, the most recent ones being published by: Pârvulețu et al., (2016); Gogoașe et al., (2016) and Drobot et al., (2014).

Considering that dam breach floods can happen and their effects can be disastrous, inundation maps for hypothetical dam failure could be very useful for vulnerability and risk assessments. Such kind of information should be of great concern for local authorities in order to adopt better regulations, policies concerning settlement or urban expansion and to mitigate the potential flood effects. Thus, this study addresses the hypothetical breach of Cătămărăști Dam, an earth dam of high dimensions that was built on Sitna River, upstream of Botoșani city. For mapping the hypothetical flood and the potential vulnerable areas, the analysis was carried out as a 2D unsteady flow modelling using HEC-RAS 5.0.5 and ArcGIS software.

\section{STUDY AREA}

The study area is given by the downstream sector of Cătămărăști Dam, over a distance of approximately $14.5 \mathrm{~km}$. Cătămărăști reservoir is part of Sitna River basin, a right-side tributary of Jijia River, located in the North-Eastern part of 
Romania, sprawled over the central and southern part of Botoșani County. The hydrographic basin of Sitna River covers an area of $943 \mathrm{~km}^{2}$, with a river length of 78 km. It discharges in Jijia River, near Hlipiceni commune (Fig. 1).

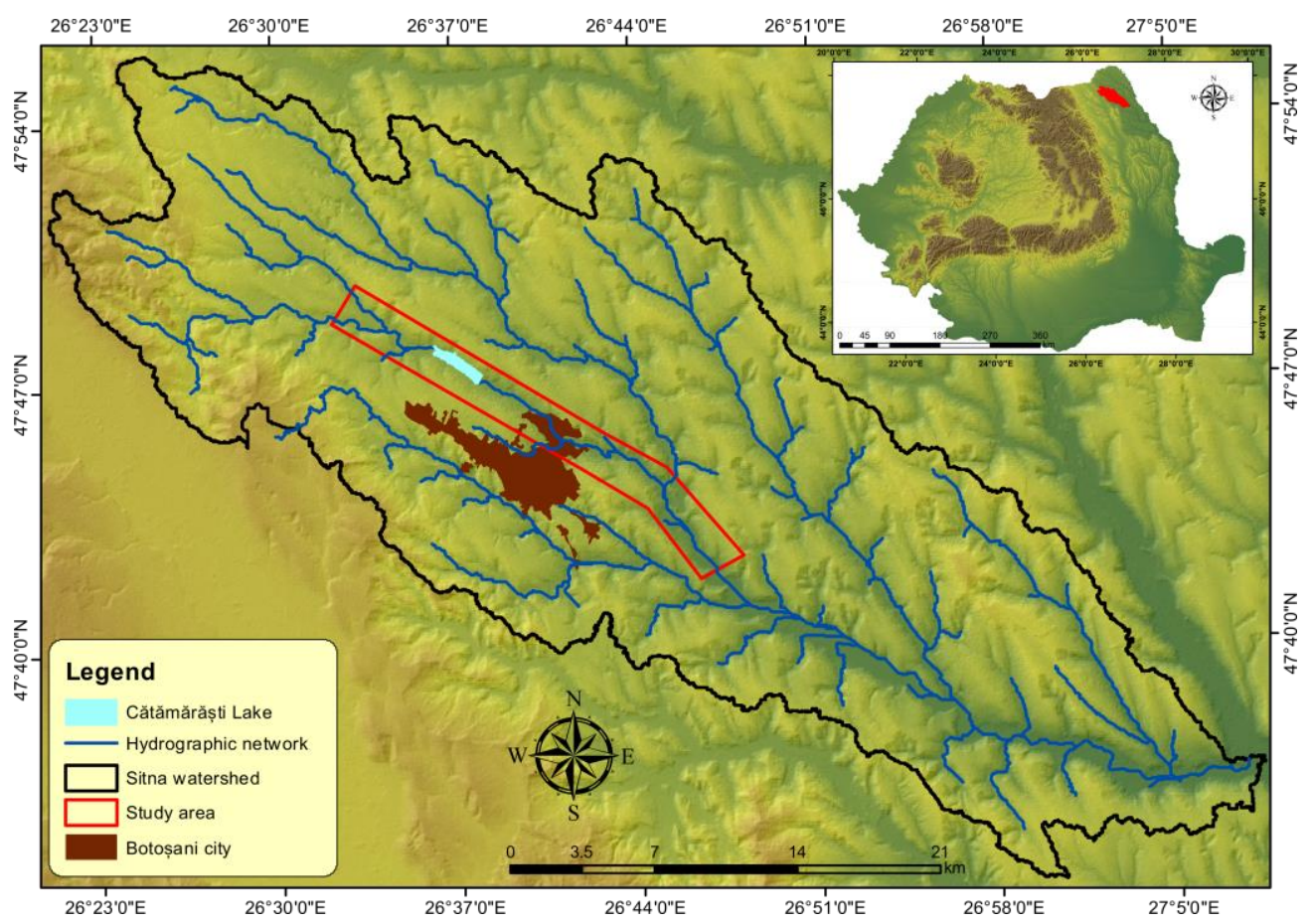

Fig. 1. Geographical location of Cătămărăști reservoir within Sitna river valley and study area

According to the Romanian Register of Big Dams, Cătămărăşti reservoir represents an artificial waterbody with a non-rock/gravel padded type of base layer, having a length of $2.6 \mathrm{~km}$ and a surface of 160 hectares. The homogenous earth dam with clay sealing has a height of 15 meters and a length of 540 meters, being constructed in 1979. The spillway of the dam is composed as it follows: a spillway with free discharge at the top and a system of penstocks at the bottom. The spillway maximum discharge rate is $157 \mathrm{~m}^{3} / \mathrm{s}$. The main purpose of the reservoir is mostly for irrigation, fish farming and flood attenuation (Vieru et al., 2010; The Romanian Register of Big Dams, 2018).

\section{DATA AND METHODS}

The dam-break simulation methodological workflow involved several steps (Fig. 2). Flood analysis is known for having an accuracy proportional with the resolution of the used Digital Elevation Model. For high quality results the most suitable terrain data that could be used was in the form of a DEM derived from LiDAR data, with a spatial resolution of $1 \times 1$ meters/pixel. The LiDAR systems have the capability of 
providing high density and high accuracy DEM data (Kabite, 2017). In order to be usable for modelling, the terrain data was first converted into Hierarchical Data Format (HDF) and imported in HEC-RAS environment via RAS-Mapper.

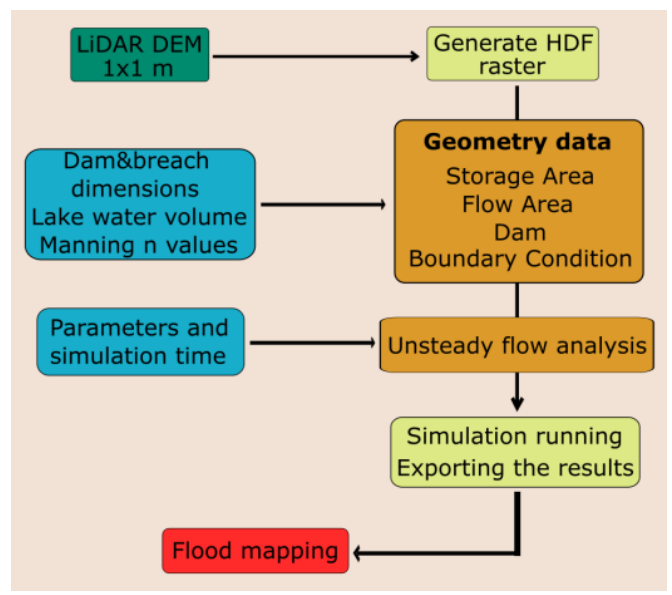

Fig. 2. Dam-break simulation methodological workflow

The first step consisted of defining the geometric data for the study area. This step implied the digitization of Cătămărăşti reservoir as a Storage Area and the downstream area (Fig. 3), where the dam-break flood will be simulated as 2D Flow Area (USACE, 2016a; USACE, 2016b).

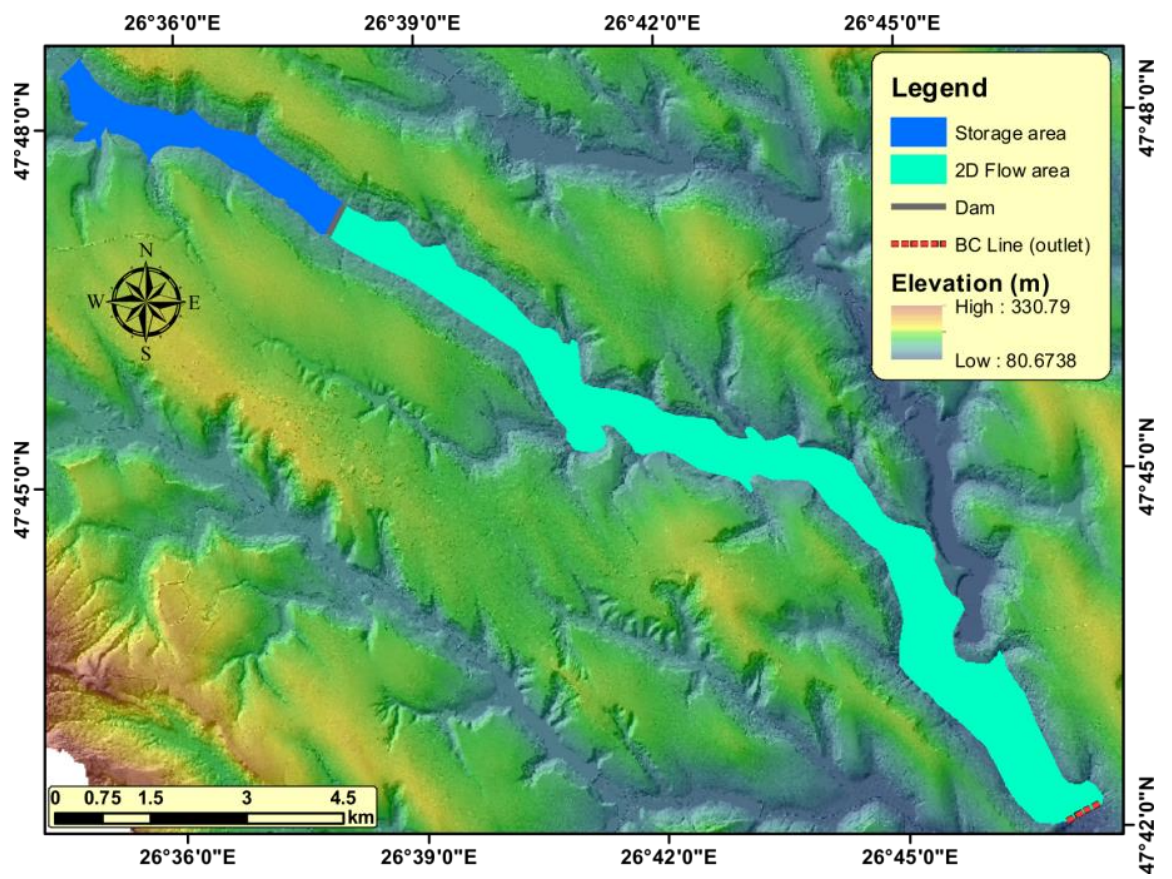

Fig. 3. The input geometry data used for the dam-break simulation 
The mesh generated by using the 2D Flow Area option acts in a similar manner to the cross-sections used in one-dimensional simulations. The difference consists in the fact that a mesh can better use the altitudinal data extracted from the DEM according to the size of the cells (computational cell spacing), especially on smaller areas, as the simulation process becomes heavier with smaller cell sizes. For this analysis, due to the low terrain roughness, the generated cell size was of 20x20 meters/pixel. The input data for the Storage Area geometry layer that followed to be simulated corresponds to the maximum water volume that the reservoir can hold, namely 12.4 million $\mathrm{m}^{3}$.

Cătămărăști Dam was digitized as a line, by using the SA/2D Area Conn tool, modelling the dam as a weir. Through defining the inline structure by using the aforementioned tool, the previously generated geometry layers, namely Storage Area and 2D Flow Area, were connected. For theoretical reasons, the spillway was considered to be clogged.

The next step consisted of defining the failure mode, the dam breach size and time of formation. These parameters were successfully inserted into the breach plan data by selecting the failure mode as overtopping and the time for the breach to form of 1 hour. By convention, the shape of the dam breach was assumed to have a trapezoid shape (Fig. 4).

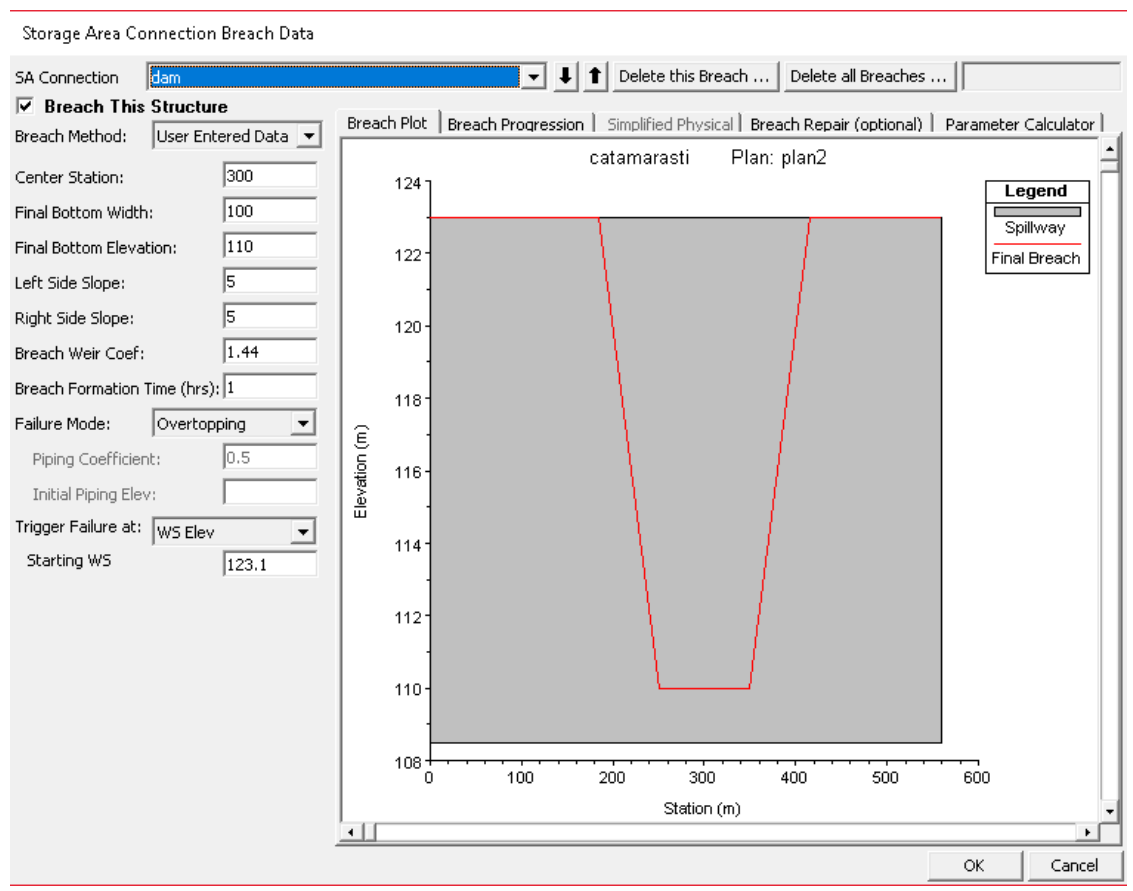

Fig. 4. Dam breach trapezoid overtopping failure

The Boundary Condition represents an important parameter as part of the analysis, which can be critical concerning dam-break simulation, as it can affect the characteristics of the generated flood. There are two types of Boundary Conditions, 
namely inlet and outlet. Consequently, they need to be properly selected for an analysis and also to be able to accurately represent the site conditions.

In a more complex analysis, by considering additional data, detailed hydrological input is needed to be able to simulate a more realistic scenario, like inflow data (Xiong, 2011). Due to the limited available data, only one Boundary Condition was considered, namely the outlet, following the water volume modelling by taking into account the Elevation-Volume parameter and the Normal Depth parameter for the outlet. As a final input, for the downstream area, the Manning's roughness coefficient (n) values were set as 0.06 , due to the fact that the land use pattern mainly consists of agricultural land, pastures and other grass formations. These values were selected after consulting aerial imagery of the area and the land cover data provided by Urban Atlas 2012 (https://land.copernicus.eu/local/urban-atlas/urban-atlas-2012).

After setting all the input data, the final step was to run the simulation by specifying the run time period (12 hours).

\section{RESULTS AND DISCUSSIONS}

The target of this analysis is to identify the vulnerable areas downstream of Cătămărăști Dam in case of a dam-break flood scenario. This could help local authorities to have a more detailed view over the potential danger the area might face, in order to develop safety policies and evacuation strategies in case of a real threat. Because Botoșani city and other localities are in the close vicinity of Cătămărăști dam, they are exposed by default to danger in case of dam failure, thus the analysis was made by taking into account the failing of the dam at full capacity.

Following the successfully carried out simulation by using the HEC-RAS 2D unsteady flow analysis module, the results were mapped by using ArcGIS software. The first map shows the full output of the dam-break simulation, the flood extent, depth and affected settlements (Fig. 5). As it can be seen in the map below, for the chosen study area, the settlements that are vulnerable in case of a dam-break are the northern side of Botoșani city periphery, Stăuceni, Răchiți and Roșiori villages.

Due to the fact that most of the vulnerable constructions and households are positioned in the administrative area of Botoșani city and Răchiți commune, the analysis will focus more on them. Concerning this aspect, Figure 6 shows the dambreak flood extent and the potential vulnerable constructions and households over the affected areas.

The total number of potentially vulnerable constructions and households for the affected areas of Botoșani city periphery and Răchiți commune counts 698, with 317 in Botoșani city periphery, and 381 in Răchiți commune. A number of roads and streets are also counted as vulnerable to the flood as follows: segments of primary roads like DN29 and DN29D count a vulnerable length of $1.45 \mathrm{~km}$, secondary roads like DJ296 present $2.9 \mathrm{~km}$ of vulnerable length, resulting 19.97 $\mathrm{km}$ of total vulnerable road length for the entire study area. 


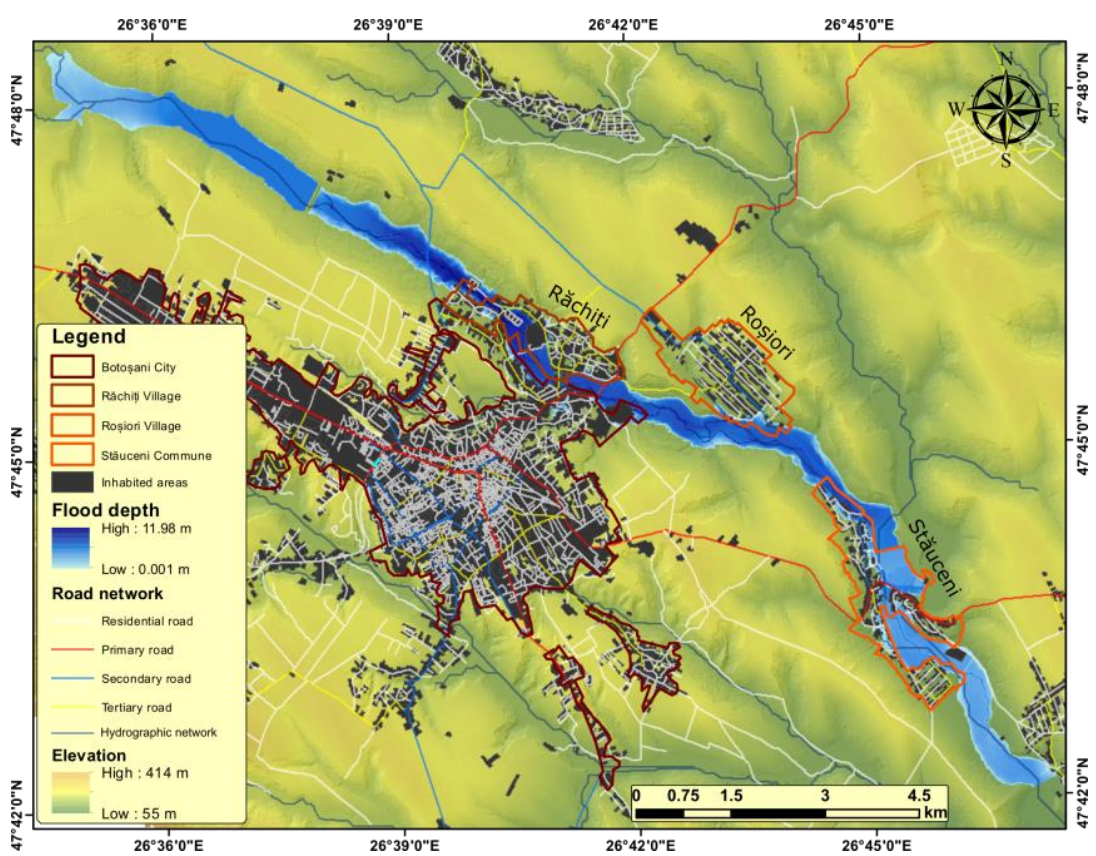

Fig. 5. Dam-break simulation output at full extent

A number of 4 bridges are also vulnerable to the flash flood, all being located across Sitna River in the area of Botoșani city and Răchiți commune, as seen in Fig. 6.

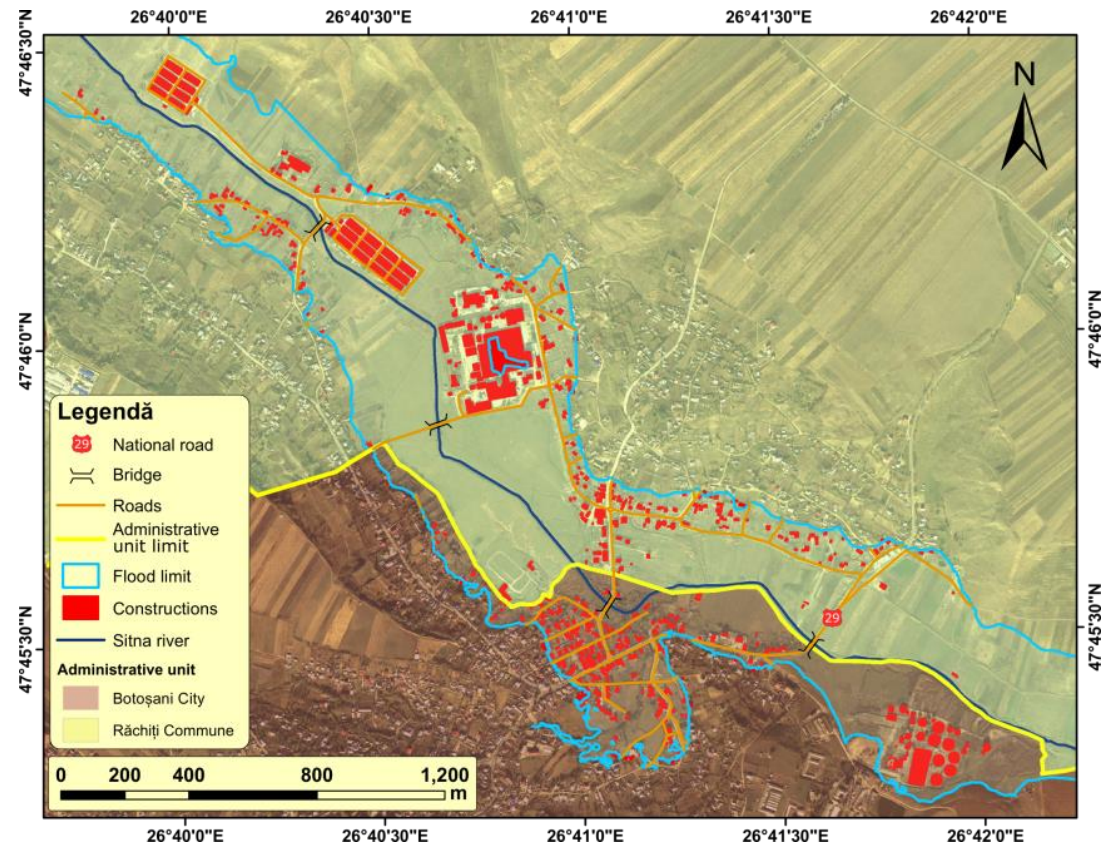

Fig. 6. Dam-break flood extent showing the vulnerable constructions and households 


\section{in Răchiți commune and Botoșani city periphery}

As a final product of the dam-break flood vulnerability analysis, a map of flood water depth was achieved (Fig. 7.). Thus, the water depths vary significantly, from upstream towards the downstream of the valley. The depth values also drop from the channel towards the sides of the flood band. The depth values are the highest at the entrance of the flood wave in the inhabited areas, covering large portions of land towards downstream where the flood becomes wider and affects Botoșani city and Răchiți commune.

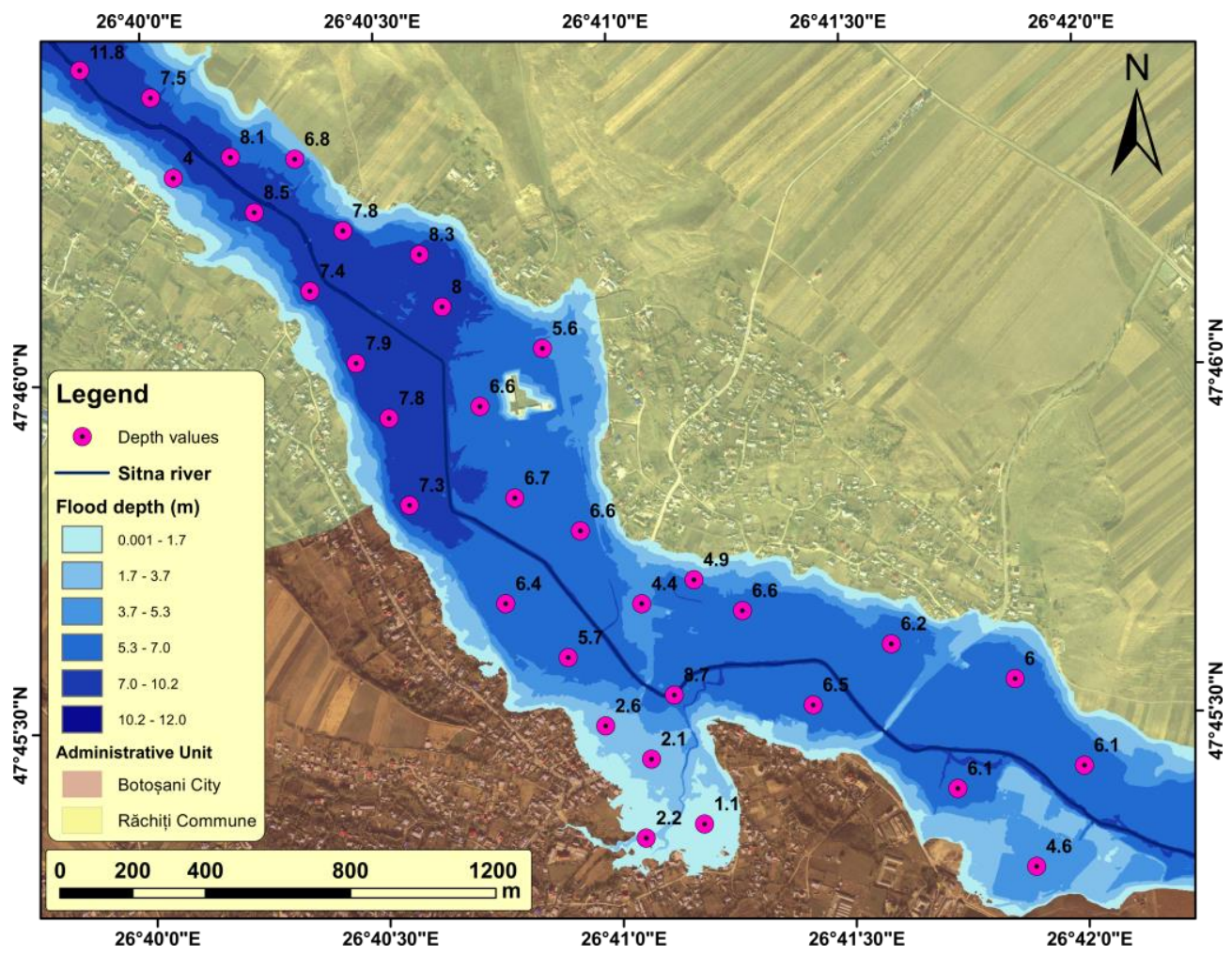

Fig. 7. Flood water depth of the simulated flash flood

By overlaying the land cover data obtained from Urban Atlas 2012 with the simulated flash flood extent, an inventory of the vulnerable areas by land cover types for the study area was obtained (Table 1).

According to the Urban Atlas 2012 data for the entire study area, Pastures and Arable lands categories count for the most vulnerable lands, followed by Isolated structures, Industrial, commercial, public and private units, fish farms etc. The total vulnerable area adds up to 780.92 hectares.

At the same time, by overlapping the land cover layer with the flood layer, as it can be seen in the table above, the average and maximum depth values for each type of land have been generated. This highlights the vulnerability of each type of 
land, the mean values indicating a scenario where the flood depth values could span between $1.76 \mathrm{~m}$ and $5.23 \mathrm{~m}$ in the study area.

Table 1. Vulnerable areas affected by simulated dam-break flood, with average and maximum flood depth values for each area

\begin{tabular}{|l|r|r|r|}
\hline \multicolumn{1}{|c|}{ Land Cover } & Affected area (ha) & \multicolumn{1}{c|}{ Mean depth (m) } & \multicolumn{2}{c|}{ Max depth (m) } \\
\hline $\begin{array}{l}\text { Continuous urban } \\
\text { fabric }\end{array}$ & 2.54 & 2.63 & 7.09 \\
\hline Isolated structures & 54.10 & 3.14 & 11.82 \\
\hline $\begin{array}{l}\text { Industrial, commercial, } \\
\text { public, military and } \\
\text { private units }\end{array}$ & 30.01 & 5.23 & 3.81 \\
\hline Construction sites & 1.19 & 2.66 & 1.94 \\
\hline $\begin{array}{l}\text { Land without current } \\
\text { use }\end{array}$ & 0.55 & 1.76 & 3.12 \\
\hline $\begin{array}{l}\text { Sports and leisure } \\
\text { facilities }\end{array}$ & 4.48 & 2.41 & 11.87 \\
\hline $\begin{array}{l}\text { Arable land (annual } \\
\text { crops) }\end{array}$ & 274.30 & 4.07 & 11.99 \\
\hline Pastures & 379.82 & 4.83 & 4.88 \\
\hline Water (fish farms) & 23.95 & 3.20 & 11.12 \\
\hline $\begin{array}{l}\text { Other roads and } \\
\text { associated land }\end{array}$ & 9.98 & 3.71 & \\
\hline TOTAL & $\mathbf{7 8 0 . 9 2}$ & & \\
\hline
\end{tabular}

The maximum depth values, though less considerable, are completing the framework of the analysis, with values between $1.94 \mathrm{~m}$ and $11.99 \mathrm{~m}$, indicating how high the flood level can rise over the study area.

Taken as a whole, the dam-break vulnerability analysis revealed that in case of such an event, a large area can be affected by the resulting flood, highlighting the vulnerable areas where the authorities could focus in case of imminent threat.

\section{CONCLUSIONS}

The flood was generated over a length of $14.5 \mathrm{~km}$ downstream of the dam, mainly for methodological purposes, but also due to the lack of sufficient data concerning the hydrological parameters of the river, more detailed terrain data, as the LiDAR data does not encompass the land changes from Sitna river valley. For a more complex study, socio-economic and census data would provide a better framework for a more detailed study, involving more criteria to be considered in order to generate results of higher accuracy.

The proximity of the settlements downstream of Cătămărăști Dam is a good indicator that, in case of imminent disaster, an important number of households, constructions and people are vulnerable. As the obtained results have revealed, following the simulation, the flood maps offer a general perspective about the risk involving the failure of Cătămărăști Dam.

Overall, HEC-RAS 5.0.5 offered a suitable methodological framework for the study, the results having the possibility to serve as a helpful material for local 
authorities when taking into consideration the protection of the population downstream of the dam location, and for minimizing the potential economic damages.

\section{ACKNOWLEDGEMENTS}

This work was technically supported by the Department of Geography, Faculty of Geography and Geology, from the "Alexandru Ioan Cuza" University, of Iasi, and the infrastructure was provided through the POSCCE-O 2.2.1, SMIS-CSNR 13984-901, No. 257/28.09.2010 Project, CERNESIM. We are grateful to Prut-Bârlad Water Administration, who provided the terrain model, derived from LIDAR data.

\section{REFERENCES}

1. Alcrudo, F. and Mulet, J. (2007), Description of the Tous Dam break case study (Spain). Journal of Hydraulic Research, 45(sup1), pp.45-57, DOI: https://doi.org/10.1080/00221686.2007.9521832.

2. Altinakar MS, McGrath MZ, Ramalingam VP et al., (2010), 2D modeling of Big Bay dam failure. In: Dittrich, Koll, Aberle, Geisenhainer (eds) Mississippi: comparison with field data and 1D model results, river flow 2010. (C) 2010 Bundesanstalt $f €$ ur Wasserbau. ISBN 978-3-939230-00-7.

3. Álvarez, M.; Puertas, J.; Peña, E.; Bermúdez, M., (2017), Two-dimensional dambreak flood analysis in data-scarce regions: The case study of Chipembe dam, Mozambique, Water, 9, 432.

4. Amini, A., Arya, A., Eghbalzadeh, A. and Javan, M., (2017), Peak flood estimation under overtopping and piping conditions at Vahdat Dam, Kurdistan Iran, Arabian Journal of Geosciences, 10(6).

5. Copernicus Land Monitoring Service - https://land.copernicus.eu/local/urbanatlas/urban-atlas-2012 (accessed 10.12.2018).

6. Enea A., (2017), Metode şi tehnici moderne de cuantificare a vulnerabilităţii la inundaţii în bazinul hidrografic Tazlău, PhD Thesis, Alexandru Ioan Cuza University, pp. 192.

7. Fu, X., Gu, C., Su, H. and Qin, X. (2018). Risk Analysis of Earth-Rock Dam Failures Based on Fuzzy Event Tree Method. International Journal of Environmental Research and Public Health, 15(5), p.886, doi:10.3390/ijerph15050886.

8. Gogoaşe Nistoran D.E., Gheorghe Popovici D.A., Savin B.A.C., Armaş I., (2016), GIS for Dam-Break Flooding. Study Area: Bicaz-Izvorul Muntelui (Romania). In: Boştenaru Dan M., Crăciun C. (eds) Space and Time Visualisation, Springer, Cham.

9. Hu H, Zhang J, Li T., (2018), Dam-Break Flows: Comparison between Flow-3D, MIKE 3 FM, and Analytical Solutions with Experimental Data, Applied Sciences, $8(12): 2456$.

10. Kabite, Gizachew., (2017), LiDAR DEM Data for Flood Mapping and Assessment; Opportunities and Challenges: A Review. Journal of Remote Sensing \& GIS. 06. 10.4172/2469-4134.1000211.

11. Macklin M., Brewer P., Balteanu D., Coulthard T., Driga B., Howard A., Zaharia S., (2003), The long-term fate and environmental significance of contaminant metals 
released by the January and March 2000 mining tailings dam failures in Maramureș County, upper Tisa Basin, Romania, Applied Geochemistry, Elsevier, vol. 18, issue 2, pp. 241-257, DOI: https://doi.org/10.1016/S0883-2927(02)00123-3.

12. Pîrvuleţu, M. and Drăghia, A., (2016), Dam Failure Effects on Local/Regional Critical Infrastructures, Mathematical Modelling in Civil Engineering, 12(3).

13. Radu Drobot, Draghia Aurelian-Florentin, (2014), Scenarii de cedare a barajului Lacul Morii de pe râul Dâmbovița și delimitarea zonelor afectate de unda de rupere, Rev. Hidrotehnica, vol. nr.59, nr. 12, p. 47-63, ISSN 0439-0962.

14. Romanescu, G., Romanescu, A. M., Romanescu, G., (2014), History of Building the Main Dams and Reservoirs, In Proceedings of the 2nd International Conference on Water resources and wetlands, Tulcea, Romania, pp. 11-13, ISSN: 2285-7923.

15. Singh V., (1996), Dam breach modeling technology, Springer Science + Business Media, pp. 255, ISBN 978-94-015-8747-1.

16. The Romanian Register of Big Dams http://www.baraje.ro/rrmb/rrmb_idx.htm (accesed 14.02.2018)

17. US Army Corps of Engineers. Hydrologic Engineering Center - USACE, (2016a), HEC-RAS River Analysis System. 2D Modelling User's Manual, pp. 171,.

18. US Army Corps of Engineers. Hydrologic Engineering Center - USACE, (2016b), HEC-RAS River Analysis System. Applications Guide, pp. 519.

19. Vieru D. N., Vieru N. P., (2010), The evaluation of the risk for floodings on the territory of Botoșani municipal town. GEOREVIEW: Scientific Annals of Stefan cel Mare University of Suceava, Geography Series, vol. 19, no. 1, pp. 81-90. ISSN: 1583-1469

20. Xiong, Y., (2011), A dam break analysis using HEC-RAS. Journal of Water Resource and Protection, vol. 3, issue 6, pp. 370-379, DOI:10.4236/jwarp.2011.36047.

21. Xu Y., Zhang L., Jinsheng J., Lessons from Catastrophic Dam Failures in August 1975 in Zhumandian, China, GeoCongress 2008 - Geosustainability And Geohazard Mitigation, New Orleans, Louisiana, United States, pp. 162 - 169, DOI: 10.1061/40971(310)20.

22. Xu, F., Yang, X. and Zhou, J., (2016), Dam-break flood risk assessment and mitigation measures for the Hongshiyan landslide-dammed lake triggered by the 2014 Ludian earthquake, Geomatics, Natural Hazards and Risk, 8(2), pp.803-821.

23. Zhang L., Peng M., Chang D., Xu Y., (2016), Dam Failure Mechanisms and Risk Assessment, Wiley, Singapore, pp. 499.

24. Zhong, Q., Chen, S., Mei, S. and Cao, W., (2017), Numerical simulation of landslide dam breaching due to overtopping, Landslides, 15(6), pp.1183-1192. 
